\title{
THE RIGHT OF EUROPEAN UNION CITIZENS AND THEIR FAMILY MEMBERS TO MOVE FREELY WITHIN THE TERRITORY OF MEMBER STATES (IN THE LIGHT OF THE JUDGMENT OF THE EUROPEAN COURT OF HUMAN RIGHTS IN OLIARI V. ITALY)
}

\author{
Robert Grzeszczak*, Magdalena Gniadzik**
}

\section{Introduction}

This article deals with one of the most significant issues concerning the principle of non-discrimination on the grounds of sexual orientation in European Union law. The judgment in Oliari and Others $v$. Italy ${ }^{1}$, a milestone in the development of this principle, provides a point of reference. This paper argues that the judgment of the European Court of Human Rights,

* Professor, Department of European Law, Faculty of Law and Administration, University of Warsaw.

** PhD, Department of European Law, Faculty of Law and Administration, University of Warsaw.

This article is the result of research funded by the National Science Centre under project no. 013/11/B/HS5/03443 Wyzwania dobrych rządów w Unii Europejskiej - od rządu do rządzenia - sposoby skutecznego realizowania misji publicznej w nowoczesnym systemie wieloszczeblowego rządzenia [Challenges of good governance in the EU - transfer from governing to governance - what is the most effective way to realise the public mission in the modern multilevel governing system].

1 Oliari and Others v. Italy, Application no. 18766/11 and 36030/11, Judgement of 19.6.2015. 
based on standards deriving from the European Convention on Human Rights and Fundamental Freedoms, will influence the understanding of the principle of non-discrimination on the grounds of sexual orientation in European Union law. It can be expected that the judgment in the aforementioned case will trigger the obligation of the States to enact legislation enabling same-sex couples to enter into some kind of a relationship recognised by the State.

The right of EU citizens to move and reside freely within the territory of its Member States is the bedrock of citizenship of the European Union, established in 1992 by the Maastricht Treaty. The right of an individual to move and reside freely is one of the fundamental principles of the EU and the cornerstone of the European integration process. It underpins the freedoms of the internal market of the EU, which have to be ensured if personal and economic freedom is to be exercised. The freedoms of the internal market determine the relationships between individuals and public authorities in their home countries as well as in all other Member States. The four freedoms form the basis for questioning various restrictions, protecting oneself from, for example, discrimination, and claiming specific rights. ${ }^{2}$

This paper focuses on the analysis of the principle of non-discrimination on the grounds of sexual orientation in European Union law. The judgment in Oliari and Others v. Italy, which appears to be a milestone in the development of this principle, provides a point of reference. This paper argues that the judgment of the European Court of Human Rights (hereafter the ECHR), based on the standards deriving from the European Convention on Human Rights and Fundamental Freedoms (hereinafter the Convention), will influence the understanding of the principle of non-discrimination on the grounds of sexual orientation in European Union (hereafter the EU) law. The legal system of the EU and the legal system established by the Convention, i.e. the regional European international system of human rights protection, are closely interrelated. The interpretation of the Convention by the ECHR is binding upon the EU and the Member States which are party to the Convention.

2 A. Cieśliński, Konstrukcja prawna swobód rynku wewnętrznego Unii Europejskiej [The legal architecture of the freedoms of the internal market of the European Union], Wrocław 2013, pp. 11-13. 


\section{The principle of non-discrimination in the EU}

The principle of non-discrimination underpins the functioning of the internal market. Discrimination is a complex phenomenon, which consists not only of treating similar situations differently, but also of treating different situations similarly, in both cases with no objective and reasonable justification. In particular, it entails excluding, differentiating between, and imposing limitations on individuals on account of their membership of a particular group rather than on account of their personal characteristics, abilities, and qualifications. As illustrated, inter alia, by the Oliari case, in principle, only an act of discrimination can be subject to legal review. Individuals may experience discrimination on the grounds of particular personal characteristics such as sex, race, skin colour, ethnicity, social background, genetic features, language, religion, beliefs, political - or other - convictions, membership of a national minority, property, birth, disability, age, sexual orientation, or other feature.

Discrimination usually takes either a direct or indirect form. Direct discrimination takes place if a given person is treated less favourably, on the grounds of a particular characteristic, than another person was, is, or would be in a comparable situation. Indirect discrimination occurs when an apparently neutral treatment puts, or would put, a given person displaying a particular characteristic at a disadvantage, unless there is an objective and rational justification for such treatment. Furthermore, the applied measures resulting in the differentiation must be proportionate in order to be justified. For that reason, the examination of a case of indirect discrimination must be preceded by an in-depth evaluation of economic and social conditions occurring in the given case ${ }^{3}$.

The principle of non-discrimination constitutes a general principle of the EU, as the Court of Justice of the EU (hereafter the CJEU or the Court) pointed out as early as at the beginning of the 1970s (in the Ruckdeschel ${ }^{4}$

3 See J. Maliszewska-Nienartowicz, Dyskryminacja pośrednia w prawie Unii Europejskiej [Indirect Discrimination in European Union Law], Torun 2012, pp. 74-84, and, in relation to indirect discrimination on sexual orientation, pp. 143-151.

4 See Albert Ruckdeschel \& Co. I Hansa-Lagerhaus Ströh \& Co. v. Hauptzollamt Hamburg-St. Annen; Diamalt AG v. Hauptzollamt Itzehoe, Cases no 117/76 and 16/77, Judgment of 19.10.1977, ECLI:EU:C:1977:160. 
as well as the Moulins \& Huileries $^{5}$ cases), when it also defined the meaning of this principle. In practice, EU Member States are prohibited by law from allowing public authorities to treat any entities unfavourably on the grounds of a particular characteristic that is deemed to be an unacceptable differentiating criterion.

\section{Factual and legal circumstances of the case}

In a judgment delivered on 21.7.2015 in Oliari and Others v. Italy, the Court ruled on complaints lodged by Italian citizens engaged in same-sex relationships. The applicants argued that their inability to contract a civil partnership constituted an infringement of Article 8 (the right to respect for family life), Article 14 in conjunction with Article 8 (discrimination on the grounds of sexual orientation), as well as Article 14 in conjunction with Article 12 (the right to marry) of the Convention. Unsurprisingly, the arguments raised by the parties to the proceedings reveal Dworkin's conflict of norms.

The applicants stressed the fact that the legal recognition of family life is essential to the protection of human dignity of an individual and their wellbeing. If same-sex couples are not allowed to contract a marriage, the state should establish a legal framework providing for legal protection of their relationship. The Italian state has not met this obligation, with the government arguing that the recognition of same-sex relationships might have a negative impact on the "traditional family." The applicants additionally claimed that homosexual people living in a stable and committed relationship have the same needs regarding legal recognition and protection as heterosexual couples. Hence, same-sex couples suffer a disadvantage only because of their sexual orientation, which should be classified as a case of direct discrimination. They also pointed to a trend towards the recognition of same-sex marriages and unions in European countries. In addition, they stressed that the role of the ECHR "could not be reduced to being an 'accountant' of majoritarian domestic views." On the contrary, the ECHR should act as a guardian of the Convention and the values underpinning

5 SA Moulins \& Huileries de Pont-à-Mousson and Société coopérative Providence agricole de la Champagne v. Office national interprofessionnel des céréals, Cases no 124/76 and 20/77, Judgment of 19.10.1977, ECLI:EU:C:1977:161. 
it, such as the protection of minorities, while leaving legislative decisions to national authorities ${ }^{6}$.

Yet, according to the Italian government, Articles 8, 12, and 14 of the Convention do not oblige the States Parties to introduce the institution of a legal partnership. Each state is capable of "having cognisance of the 'common sense' of its own community," especially in such a delicate area, related to individual sensitivity as well as cultural identity. It is at the discretion of particular states to decide how much time is needed to reach an agreement within society on new family structures. The government indicated that the case law of the Court confirmed a lack of obligation of the states to recognise same-sex marriages, which means that homosexual unions do not have to be recognised either. According to the Italian government, the Court does not have a mandate to impose such an obligation. In the opinion of the government, same-sex couples can conclude civil law contracts ("contrati di convienza," which are a type of cohabitation agreements), covering issues such as common expenses, a common flat, the other person's rights in the event of physical or mental illness of their partner, wills, as well as the division of property on the dissolution of the partnership. ${ }^{7}$

\section{The position of the European Court of Human Rights}

The Court set the tone for the deliberations by reiterating that Article 8 of the Convention protects individuals from arbitrary interference of public authorities, but it may also be regarded as a source of the state's positive obligation to protect the rights contained in this article in an efficient way. The obligation may entail taking measures to protect private and family life, also in the area of relations between individuals. States have a certain degree of discretion with respect to the positive obligation, which is determined by various factors. In cases concerning crucial aspects related to the existence or identity of an individual, the discretion of the state should be limited. On the other hand, if there is no consensus between States who are parties to the Convention with respect to morally or ethically sensitive areas, the scope of discretion is broader. The States are

6 Oliari and Others v. Italy, supra note 1, at paras 106-107, 111-113.

7 Ibid., at paras 126 and 129. 
also given considerable freedom if it is necessary to strike a fair balance between conflicting private and public interests or convention rights. ${ }^{8}$

The Court noted that at the time the judgment was given in Schalk and Kopf v. Austria, ${ }^{9}$ according to which Article 14 in conjunction with Article 8 of the Convention does not oblige the States to allow same-sex couples to marry, only nineteen States Parties provided for a legal framework for same-sex relationships. This indicates that while the evolution of the rights of this group is an ongoing process, the consensus among the States is yet to be reached.

The Court emphasised that, as it remains impossible for the applicants to contract a civil partnership (or marriage) in Italy, its task is to decide whether the State meets the positive obligation to respect private and family life of the applicants in the year 2015 by providing for a legal possibility to recognise their relationship and to protect it. The Court noted that, for the time being, the majority of the States Parties (24 of 47) have enacted a legal framework providing for the recognition and protection of same-sex couples. ${ }^{10}$ The Court held that since same-sex couples are equally able to enter into stable and committed relationships as heterosexual couples, their needs concerning legal recognition and protection of their relationships are also comparable, which is in line with the previous case law of the Court. It stated that the applicants are deprived of the right to contract into a marriage, and, at the same time, they do not have access to legal institutions, such as civil partnerships, that could provide samesex couples with legal recognition and the rights that persons in stable and committed relationships should enjoy. According to the ECHR, while civil law contracts cover some issues related to living together, they do not guarantee the aforementioned rights and do not meet the criterion of permanence. ${ }^{11}$

According to the Court, the Italian legislator has failed to adopt provisions that would govern the issue of overriding social importance for almost three decades and continues to ignore the recommendations of the highest courts in Italy. It referred to a judgment of the Italian Constitutional Court, which decided that same-sex couples have the right to legal recognition of their relationship under the Italian constitution and summoned

$8 \quad$ Ibid., paras 159 and 162.

$9 \quad$ Schalk and Kopf v. Austria, Application no 30141/04, Judgment of 24.6.2013.

10 Oliari and Others v. Italy, supra note 1, at paras 163-164 and 178.

11 Ibid., at paras 165, 167 and 169. 
the legislator to incorporate such provisions into the legal system. Thus, the fact that there is no public interest that could outweigh the interests of the applicants in conjunction with the judgments of the national courts led to the conclusion that Italy has abused its discretion and has not met the positive obligation to enact national legislation granting the applicants legal recognition and protection of their relationship, which constitutes a breach of Article 8 of the Convention. ${ }^{12}$

\section{A breakthrough judgment}

The judgment in Oliari v. Italy constitutes a breakthrough, if only because, for the first time, the Court has explicitly stated that a State Party has a positive obligation to adopt legal provisions that would grant same-sex relationships legal recognition. At the same time, the judgment is a continuation of the earlier case law of the ECHR, which has been gradually empowering homosexual persons. ${ }^{13}$

It is particularly interesting to compare the aforementioned judgment with that of Vallianatos and Others $v$. Greece. ${ }^{14}$ The latter case concerned Greek law ${ }^{15}$ introducing civil partnerships for opposite-sex couples only, which, according to the applicants, constituted a breach of Article 14 in conjunction with Article 8 of the Convention. The Court held that states have to take into account the development of society and changes in the perception of social issues as well as issues related to marital status and relationships between people, including the fact that, with respect to private and family life, there is no option that would be superior to all others. It also pointed to the fact that same-sex couples are equally capable of entering into stable relationships as heterosexual couples and that they have comparable needs concerning legal recognition and protection of their relationship. Hence, it can be stated that Greek legislation, which provides for the possibility of entering into a civil partnership for opposite-sex couples only, differentiates between people on the grounds of sexual orientation.

12 Ibid., at paras 179-183 and 185-187.

13 See, inter alia, C. Grabenwarter, European Convention on Human Rights - Commentary, Munich 2014, pp. 194 and 223.

14 Vallianatos and Others v. Greece, Application no 29381/09 and 32684/09, Judgment of 7.11.2013.

15 Act no 3719/2008, which came into force on 26.11.2008. 
The Court reiterated that States Parties are granted limited discretion as regards treating people differently on the grounds of sexual orientation and that different treatment needs to be justified by particularly compelling and important reasons. Differentiation based solely on sexual orientation is inconsistent with the Convention. At the same time, the Court criticised the arguments put forward by the Greek government concerning the protection of children born out of wedlock and strengthening of the institution of a traditional marriage.

The Court added that there might be no consensus between the States party to the Convention, but there is a trend towards the provision of a legal framework for same-sex couples. However, it noted that if, due to the evolution of national legislations, a given state would be in an isolated position, this would not automatically mean the state infringes the Convention, but it would have to justify the differentiation by compelling and important reasons. Hence, the ECHR found a breach of Article 14 in conjunction with Article 8 of the Convention. The Court noted that the case does not concern the general positive obligation of the States party to the Convention to incorporate the institution of civil partnerships for same-sex couples into their legal systems, but the question whether such institution could be introduced for the exclusive benefit of opposite-sex couples.

Thus, it seems that the judgment in Oliari $v$. Italy is a further step towards the extension of the rights of same-sex couples established by the Convention. It should be noted that some authors derived the obligation to introduce some kind of same-sex partnerships by all the States party to the Convention from the judgment in Vallianatos and Others v. Greece. ${ }^{16}$ Others pointed out that the reasoning of the Court prepared the ground for acknowledging the positive obligation of legal recognition of samesex relationships in future judgments. ${ }^{17}$ On the other hand, it should be noted that the judgment in Oliari $v$. Italy can also be perceived as a missed opportunity for imposing on the Parties to the Convention a clear positive obligation to provide same-sex couples with some kind of legal recognition. Undoubtedly, the Court had strong arguments, especially in this case to justify such a change; nevertheless, one can be sure that it is not the end

16 See. I. Trispiotis, Discrimination and civil partnerships: Taking 'legal' out of legal recognition, 'Human Rights Law Review' 2014, vol. 14, at p. 350.

17 R. George, Civil Partnership, Sexual Orientation and Family Life, 'Cambridge Law Journal' 2014, vol. 73, at p. 263. 
of the process but rather a step forward towards securing equal rights for same-sex relationships.

\section{A pan-European consensus on the recognition of same- sex relationships?}

It is worth noting how the ECHR approaches the issue of a consensus between the States party to the Convention over the recognition of same-sex couples. ${ }^{18}$ In its judgment in Vallianatos and Others v. Greece, the Court pointed to a lack of a consensus evidenced by the fact that only some States have a legal framework for same-sex couples in place. It also noted that even if such a consensus was reached, the States could still justify their practices under the Convention. In its judgment in the Oliari case, the Court argued that the majority of States have such legislation in place. This seems to mean that the Court assumes the consensus has been reached; although, it has not been stated explicitly. ${ }^{19}$

This raises a question about the consequences of the judgment for the remaining States party to the Convention. On the one hand, the thesis of the ECHR concerning the positive obligation under Article 8 of the Convention to introduce some kind of a legal framework for same-sex couples suggests that the same obligation applies to the remaining States. On the other hand, it seems that the Court attached particular importance to the factual circumstances, which make the situation of Italy unique. Hence, there is doubt whether the judgment of the ECHR would be the

18 For more on the concept of consensus in the jurisprudence of the ECHR see L. Wildhaber, A. Hjartarson, S. Donnelly, No Consensus on Consensus? The practice of the European Court of Human Rights, 'Human Rights Journal' 2013, vol. 33, no 7-12, at pp. 248-263; O. Arnardottir, The Differences that Make a Difference: Recent Developments on the Discrimination Grounds and the Margin of Appreciation under Article 14 of the European Convention on Human Rights, 'Human Rights Law Review' 2014, vol. 14, at pp. 647-670.

19 With regard to married couples: Belgium, Denmark, France, Iceland, Luxembourg, the Netherlands, Norway, Portugal, Sweden and the United Kingdom; in terms of partnerships: Andorra, Austria, Belgium, Croatia, the Czech Republic, Finland, France, Spain, Germany, Ireland, Liechtenstein, Luxembourg, Malta, the Netherlands, Slovenia, Switzerland, Hungary and the United Kingdom. In Estonia, the Act of Partnership entered into force on 1.1.2016. In Finland, the Act on same-sex marriages shall enter into force on 1.1.2017. The Irish voted in a referendum on 22.5.2015. The introduction of same-sex marriage, judgment Oliari v. Italy, supra note 1 at pp 53-55. 
same in the case of countries where public opinion is split or even against such changes and where national constitutional courts have not derived the right to enter into a civil partnership from national constitutions.

A dissenting opinion submitted by three of the judges provides certain guidance in this respect. ${ }^{20}$ The judges claimed that Italy, which over a long period of time has failed to provide a legal framework for samesex couples, as derived from the constitution, breaches Article 8 of the Convention only with respect to the State's interference with the right of the applicants to respect for family life, which results in uncertainty concerning their legal status (which, in turn, constitutes a breach of the negative obligation under Article 8 of the Convention), and not as far as the positive obligation of the State is concerned. The judges found it unnecessary to decide whether Article 8 imposes an obligation on Italy and other Member States to provide a legal framework for same-sex couples. At the same time, the judges stated that:

Our colleagues are careful to limit their finding of the existence of a positive obligation to Italy and to ground their conclusion on a combination of factors not necessarily found in other Contracting States. To begin with, we are not sure that such a limitation of a positive obligation under the Convention to local conditions is conceptually possible. Secondly, at some points our colleagues nonetheless appear to rely, at least partly, on general reasoning capable of being read as implying a free-standing positive obligation incumbent on all the Contracting States to provide a legal framework for same-sex unions. ${ }^{21}$

Therefore, it seems that if a complaint is filed against another State, public authorities will have to put forward objective and convincing evidence in order to justify the refusal to provide any legal framework that would allow same-sex couples to obtain legal recognition of their relationship. In the case of an unconditional refusal of a State to establish a legal framework granting same-sex couples the right to formal recognition of their relationship, as guaranteed under Article 8 of the Convention, the State could find it difficult to convince the Court that such an omission is not in breach of the Convention, especially as an increasing number of countries will have incorporated civil partnerships and same-sex marriages into

20 The judges who submitted the opinion were Paul Mahoney (UK), Nona Tsotsoria (Georgia), and Faris Vehabović (Bosnia and Herzegovina).

21 Paragraph 10 of the dissenting opinion. 
their national legal systems. Thus, it seems that Oliari v. Italy will also have practical consequences for the remaining States party to the Convention that have yet to provide any legal framework for same-sex couples.

\section{The effect of the interpretation of the Convention on European Union law}

The judgment in the Oliari case also affects the law of the European Union, which has virtually no powers in the field of family law. The EU cannot lay down an obligation for the Member States to incorporate the institution of civil partnerships or same-sex marriages into their legal order. On the other hand, the judgment has an impact on the understanding of the rights and freedoms of the Charter of Fundamental Rights ${ }^{22}$ (hereafter the CFR) and the scope of the rights of EU citizens and their family members to move freely, as specified in Directive 2004/38. ${ }^{23}$ It should be noted that only eight out of 28 Member States have not enacted legislation on civil partnerships or same-sex marriages.

Pursuant to Article 2 of Directive 2004/38, "family member" means: (a) the spouse; (b) the partner with whom the EU citizen has contracted a registered partnership, on the basis of the legislation of a Member State, if the legislation of the host Member State treats registered partnerships as equivalent to marriage and in accordance with the conditions laid down in the relevant legislation of the host Member State; (c) the direct descendants who are under the age of 21 or are dependants and those of the spouse or partner as defined in point (b), and the dependent direct relatives in the ascending line and those of the spouse or partner as defined in point (b).

However, Article 3(2) of the Directive obliges Member States to facilitate entry and residence for, inter alia, the partner with whom the EU citizen has a durable and duly attested relationship: the host Member State shall undertake an extensive examination of the personal circumstances and shall justify any denial of entry or residence to such a person.

22 OJ C 303/207, p. 1.

23 European Parliament and Council Directive 2004/38/EC of 29.4.2004 on the right of citizens of the Union and their family members to move and reside freely within the territory of the Member States amending Regulation (EEC) No 1612/68 and repealing Directives 64/221/EEC, 68/360/EEC, 72/194/EEC, 73/148/EEC, 75/34/EEC, 75/35/ EEC, 90/364/EEC, 90/365/EEC, and 93/96/EEC, OJ 30.4.2004 L-158, p. 77. 
There is doubt whether the definition of a spouse covers persons who have contracted a same-sex marriage. The Court of Justice held that according to the definition that is given most prominence in Member States, the term "spouse" refers only to persons of the opposite sex who have concluded a marriage. ${ }^{24}$ Nevertheless, fifteen years have passed since the judgment and it seems that due to the changes that have taken place in the legislation of Member States since then, the statement has become obsolete. ${ }^{25}$ Furthermore, special attention should be paid to the judgment in case C-45/12 Ahmed, where the Court of Justice emphasised that the term "spouse" refers only to persons who have contracted a marriage, and a partner cannot be considered to be a "spouse," even in a stable relationship. ${ }^{26}$

According to legal scholars, Article 2 imposes obligation to recognise marriages only to the extent to which they would be recognised by the host country with respect to their own citizens. This means that only those Member States that enable same-sex couples to enter into a marriage are obliged to recognise such marriages concluded in other Member States. As for the countries that have introduced some kind of civil partnership for same-sex couples, it seems that they should recognise same-sex partnerships concluded in other Member States as registered partnerships. The obligation of states that have not provided any legal framework for same-sex relationships remains unspecified; although, according to legal scholars, as the EU has no powers in the field of family law, such persons shall be treated as partners only within the meaning of point $b$ of Article 3(2) of the Directive. ${ }^{27}$

The Directive defines the conditions under which a given person may be considered a family member in the case of civil partnerships. Firstly, a registered partnership shall be contracted under the legislation

24 D and Kingdom of Sweden v. Council of the European Union, Cases no C-122/99 and C-125/99, Judgment of 31.5.2001, ECLI:EU:C:2001:304, at para.39.

${ }^{25}$ Compare: J. Guth, When is a Partner not a Partner? Conceptualisation of 'family' in EU Free Movement Law, 'Journal of Social Welfare and Family Law' 2011, vol. 33, no 2, at pp. 195-196.

26 Office national d'allocations familiales pour travailleurs salariés (ONAFTS) v. Radio Hadj Ahmed, Case C-45/12, Judgment of 13.6.2013, ECLI:EU:C:2013:390, at para. 51. See also the Netherlands v. Ann Florence Reed, Case no 59/85, Judgment of 17.4.1986, ECLI:EU:C:1986:157, at paras 15-16.

27 E. Guild, S. Peers, J. Tomkin, The EU Citizenship Directive. A Commentary, Oxford 2014, pp. 34-36, see also S. Peers, T. Hervey, J. Kenner, A. Ward (eds.), The EU Charter of Fundamental Rights. A commentary, Oxford 2014, p. 209. 
of a Member State. Some claim that this condition is also fulfilled if a civil partnership is contracted in another country and the host Member State recognises civil partnerships contracted in other countries. ${ }^{28}$

The second condition to be complied with is that the legislation of the host Member State treats registered partnerships as equivalent to marriage. There is some doubt as to how to interpret the notion of equivalence. If it was interpreted narrowly, nearly no civil partnership could be treated as equivalent to marriage as these two frameworks are separate legal institutions. Therefore, as this interpretation deprives the provision of effectiveness, it does not seem appropriate. As a result, it is possible to require that such partnerships grant rights comparable to the rights of married couples, particularly with respect to immigration law. ${ }^{29}$

For the above reasons, same-sex couples, who, under national legislation, cannot contract a civil partnership or marriage, and in the case of some Member States, also persons, who have contracted such partnerships, shall be treated as partners only within the meaning of Article 3(2) of Directive 2004/38. This entails demonstrating to the authorities of the host Member State that the relationship is durable, which means it has lasted for a given period of time. Member States usually require the couple to have lived together for a specified period of time and to perceive their relationship as durable. ${ }^{30}$ No such obligation exists in the case of spouses and partners in a registered partnership within the meaning of Article 2 of the Directive, which results in the fact that they are not faced with uncertainty as to the decisions taken by the authorities of the host Member State. Another problem might be the requirement to present evidence suggesting that the partnership has lasted for the required period of time. ${ }^{31}$

In its judgment in case C83/11 Rahman, the Court of Justice clarified the scope of obligations under Article 3(2) for Member States. ${ }^{32}$ According to the judgment, Member States are not obliged to grant every application for entry or residence submitted by family members of an EU citizen if the applicants do not meet the definition of a "family member" as set out in Article 2(2) of the Directive. National legislation should only specify the

8 See E. Guild, S. Peers, J. Tomkin, op. cit., p. 40.

29 Ibid., pp. 40-41; J. Guth, op. cit., at p. 196.

30 J. Guth indicates a period of two years, see: ibid., p. 198.

31 Ibid.

32 Secretary of State for the Home Department v. Muhammad Sazzadur Rahman and others, Case no C-83/11, Judgment of 5.9.2012, ECLI:EU:C:2012:519, at para.26. 
criteria for obtaining a decision on the application for entry or residence on the basis of an extensive examination of personal circumstances. If permission is not granted, the decision should state the reasons. Each applicant has the right to appeal against the decision to the court.

Hence, Directive 2004/38 is not sufficient to protect the right to respect for family life of same-sex couples, both those who have contracted a civil partnership and those who have not had such a possibility. The scope of their rights related to the right of free movement depends on national legislation, which may or may not authorise the entry and residence of such persons, provided that it does not violate the principle of non-discrimination on the grounds of nationality. On the one hand, the fact that it has been left to Member States to make this decision results from a lack of powers on the part of the EU in the field of family law and a lack of consensus among Member States as to the rights of same-sex couples. On the other hand, this constitutes a serious obstacle for EU citizens and their family members with respect to exercising the right of free movement. It seems, namely, that such persons might become discouraged to reside in a Member State which does not recognise legal partnerships and same-sex marriages as the status of their relationship would be uncertain. Hence, the compatibility of this regulation with Articles 21, 45, and 49 of the TFEU may be called into question. The Court of Justice has not yet had the opportunity to decide on the matter. ${ }^{33}$ Legal scholars have also claimed that the regulation contained in Articles 2 and 3 of Directive 2004/38 constitutes discrimination on the grounds of sexual orientation. ${ }^{34}$

Directive 2004/28, as secondary law, must be compatible with primary law, including the Charter of Fundamental Rights, which, in Article 7, states that everyone has the right to respect for their private and family life, home and communications, and, in Article 9, that the right to marry and have a family shall be guaranteed in accordance with the national law governing the exercise of these rights.

It should be noted that under Article 52(3) of the Charter of Fundamental Rights, the meaning and scope of the rights guaranteed by the Charter are equivalent to those of the corresponding articles of the Convention, which does not preclude wider protection being granted

33 Questions posed by a Hungarian court concerning 2 paragraphs 2 point b) have been removed by the court, see CJEU decision of 16.7.2015 in Case C-459/14 Cocaj, ECLI:EU:C:2015:546.

34 J. Guth, op. cit., at p. 193-199. 
by European Union law. In its judgment in case $C-400 / 10 \mathrm{McB}$, the Court of Justice concluded that the right to family life guaranteed by Article 7 of the Charter of Fundamental Rights corresponds to Article 8 of the Convention, stating that "Article 7 of the Charter must therefore be given the same meaning and the same scope as Article 8(1) of the Convention, as interpreted by the case law of the European Court of Human Rights." ${ }^{35}$ It is of great significance that the Court of Justice confirmed also the effects of the interpretation of Article 8 of the Convention by the European Court of Human Rights on the scope of rights guaranteed by Article 7 of the Charter of Fundamental Rights.

\section{Conclusion}

It can be expected that the judgment in Oliari v. Italy will trigger an obligation for States to enact legislation enabling same-sex couples to enter into some kind of a relationship recognised by the State. The same obligation arises from Article 7 of the Charter of Fundamental Rights, which constitutes part of the primary law of the EU. This does not mean, however, that Article 7 could become the basis for the EU to impose the institution of legal partnerships on Member States that have not yet enacted such regulations. Pursuant to Article 51 of the Charter of Fundamental Rights, the provisions of the Charter are addressed to Member States only when they are implementing EU law. Moreover, the Charter does not provide the EU with any new powers. ${ }^{36}$

Nevertheless, Article 7 of the Charter applies to areas where the EU has been given powers by the Treaties, including the right of citizens of the Union and their family members to move freely. If the right to respect for family rights results in the right of same-sex couples to obtain legal recognition of their relationship under national legislations, and if the States have a positive obligation to provide a legal framework for civil partnerships, then this right, more importantly, provides for the obligation of the States to acknowledge the fact that persons who have contracted a civil partnership are family members to each other. This recognition is

35 PPU J. McB. v. L. E., Case no C-400/10, Judgment of 5 October 2010, ECLI:EU:C:2010:582, at para. 53.

${ }^{36}$ More on the effects of Article 51 and 52 CFR see S. Peers, T. Hervey, J. Kenner, A. Ward (eds.), op. cit., pp. 1413-1454 and 1490-1503. 
at the very core of the right to respect for family life. Hence, the refusal of a Member State to give permission for entry and residence to a person who has contracted a civil partnership with an EU citizen should be considered to be an infringement of Article 7 of the Charter. By the same token, the refusal to give permission for entry and residence to a partner of an EU citizen of the same sex, provided that the relationship meets the criterion of permanence, would also constitute a breach of the right to respect for family life.

\section{Bibliography}

O. Arnardottir, The Differences that Make a Difference: Recent Developments on the Discrimination Grounds and the Margin of Appreciation under Article 14 of the European Convention on Human Rights, 'Human Rights Law Review' 2014, vol. 14.

A. Cieśliński, Konstrukcja prawna swobód rynku wewnętrznego Unii Europejskiej [The legal architecture of the freedoms of the internal market of the European Union], Wrocław 2013, pp. 11-13.

R. George, Civil Partnership, Sexual Orientation and Family Life, 'Cambridge Law Journal' 2014, vol. 73.

C. Grabenwarter, European Convention on Human Rights - Commentary, Munich 2014.

E. Guild, S. Peers, J. Tomkin, The EU Citizenship Directive. A Commentary, Oxford 2014.

J. Guth, When is a Partner not a Partner? Conceptualisation of 'family' in EU Free Movement Law, 'Journal of Social Welfare and Family Law' 2011, vol. 33.

J. Maliszewska-Nienartowicz, Dyskryminacja pośrednia w prawie Unii Europejskiej [Indirect Discrimination in European Union Law], Torun 2012.

S. Peers, T. Hervey, J. Kenner, A. Ward (eds.), The EU Charter of Fundamental Rights. A commentary, Oxford 2014.

I. Trispiotis, Discrimination and civil partnerships: Taking 'legal' out of legal recognition, 'Human Rights Law Review' 2014, vol. 14.

L. Wildhaber, A. Hjartarson, S. Donnelly, No Consensus on Consensus? The practice of the European Court of Human Rights, 'Human Rights Journal' 2013, vol. 33. 